\title{
Soil Erosion Risk Mapping Using the Analytical Hierarchy Process (AHP) and Geographic Information System in the Tifnout-Askaoun Watershed, Southern Morocco
}

\author{
Abdellaali Tairi, PhD Student \\ Ahmed Elmouden, Professor
}

Laboratory of Applied Geology and Geo-Environment, Department of Geology Faculty of Science Ibn Zohr Agadir, Morocco

\section{Mohamed Aboulouafa,}

Laboratory of Materials, Electrochemistry and Environment, Department of Chemistry, Faculty of Science, Ibn Tofail University, Kenitra, Morocco

Doi:10.19044/esj.2019.v15n30p338 URL:http://dx.doi.org/10.19044/esj.2019.v15n30p338

\begin{abstract}
Soil erosion, a natural process accelerated by humans, is one of the serious environmental problems facing farmers in the Tifnout Askaoun watershed in the Taroudant province of southern Morocco. The objective of this study is the qualitative mapping of areas at risk of water erosion in the Tifnout Askaoun watershed using the AHP method (Analytical Hierarchy Process), this method consists of a weighting of the factors adopted by a comparison. in pairs of factors that control erosion in this area. The main factors considered in this study are slope, drainage density, land use, soil erodibility and erosivity of precipitation. The erosion risk map obtained for the study area shows that the erosion phenomenon is threatening the TifnoutAskaoun region in southern Morocco.The risk map has four classes ranging from low to very high erosion risk. It shows that more than $48 \%$ of the study area has a high to very high risk of erosion. The result shows that erosion is very strong in the northern part of the study area around the Ifni lake, while the risk becomes low in the south near the Aoulouz and Mokhtar Soussi dams. The study has shown that the phenomenon of water erosion is very intense in the areas located in the High Atlas and the areas located in the Anti Atlas presents a risk of erosion low to medium.
\end{abstract}

Keywords: Soil erosion, AHP, GIS, Tifnut-Askaoun, watershed, Morocco 


\section{Introduction}

Soil erosion is a phenomenon that affects the majority of environmental components; the soil by loss and degradation, water by its degradation of its quality and quantity and vegetation by the sterilization of soils by the decrease of organic matter which causes desertification. This phenomenon also has adverse consequences for agglomerations and hydraulic structures downstream of the watersheds, which leads to flooding.

Erosion is a natural and / or anthropogenic phenomenon affecting all regions of the world; it is very accentuated especially in regions with arid and semi-arid climates like the Mediterranean zone of which Morocco is a part.

In Morocco, as everywhere in the world, water erosion of soils is linked to several physico-climatic and anthropogenic factors, and poses several problems with socio-economic and environmental consequences; water erosion has consequences both in eroded zones upstream, where it could lead to desertification, and downstream in deposition zones where it can cause siltation of structures (Elmouden, 2017).

Many methods have been developed for the quantification and calculation of the erosion rate either measured directly in the field or it is estimated by soil analyzes or empirical or physical models and equations that take into account the impact of all variables of water erosion.

The geographical position of the study area between the high altitudes of the High Atlas and the plain of Souss, its shape, its highly variable rainfall, its rivers, its steep slope, and its poorly developed soils, make the area exposed to water erosion.

Remote sensing and geographic information systems (GIS) are also used to study the erosion phenomenon and are effective tools for interactive decision support systems for risk management operations. (Boukheir et al., 2006).

Analytic hierarchy process (AHP) is continues to be one of the most popular analytical techniques for complex decision making problems and is widely used due to its flexibility and easy to use. An AHP hierarchy can have many levels to characterize a decision condition.

The selected factors governing the suitability of the site are weighted using the Analytical Hierarchy Process (AHP) which is aided by pairwise comparison matrix that uses a scale of relative importance (Al Raisi et al. 2014).

\section{Study area}

The "Tifnout-Askaoun" zone is located between the latitudes North 30 $\circ 35^{\prime}$ 'and $31^{\circ} 05^{\prime}$ ', and the longitudes West $7^{\circ} 37$ 'and $8^{\circ} 11^{\prime}$ '. This zone includes, in the north, the large Tifnout valley, which represents the southern flank of the Western High Atlas Mountains, and the south Askaoun zone 
which represents the Siroua chain of the Anti-Atlas. This highly mountainous region is intensely dissected to the north by the Assif of Tifnout and to the south by the different wadis of Askaoun. It is characterized by a rugged and very rugged topography with an altitude ranging from $765 \mathrm{~m}$ in the southern part of the Tifnout valley to $4132 \mathrm{~m}$ near the summit of Toubkal (fig. 1).

East of the Tifnoute Valley, the topography is less rugged, although it includes high volcanic mountains associated with the Sirwa complex such as Jbel Agandiy $(2684 \mathrm{~m})$. The entire region is generally difficult to access by vehicle, with few trails beyond the road along the valley, most villages are distant and accessible only by foot or mule.

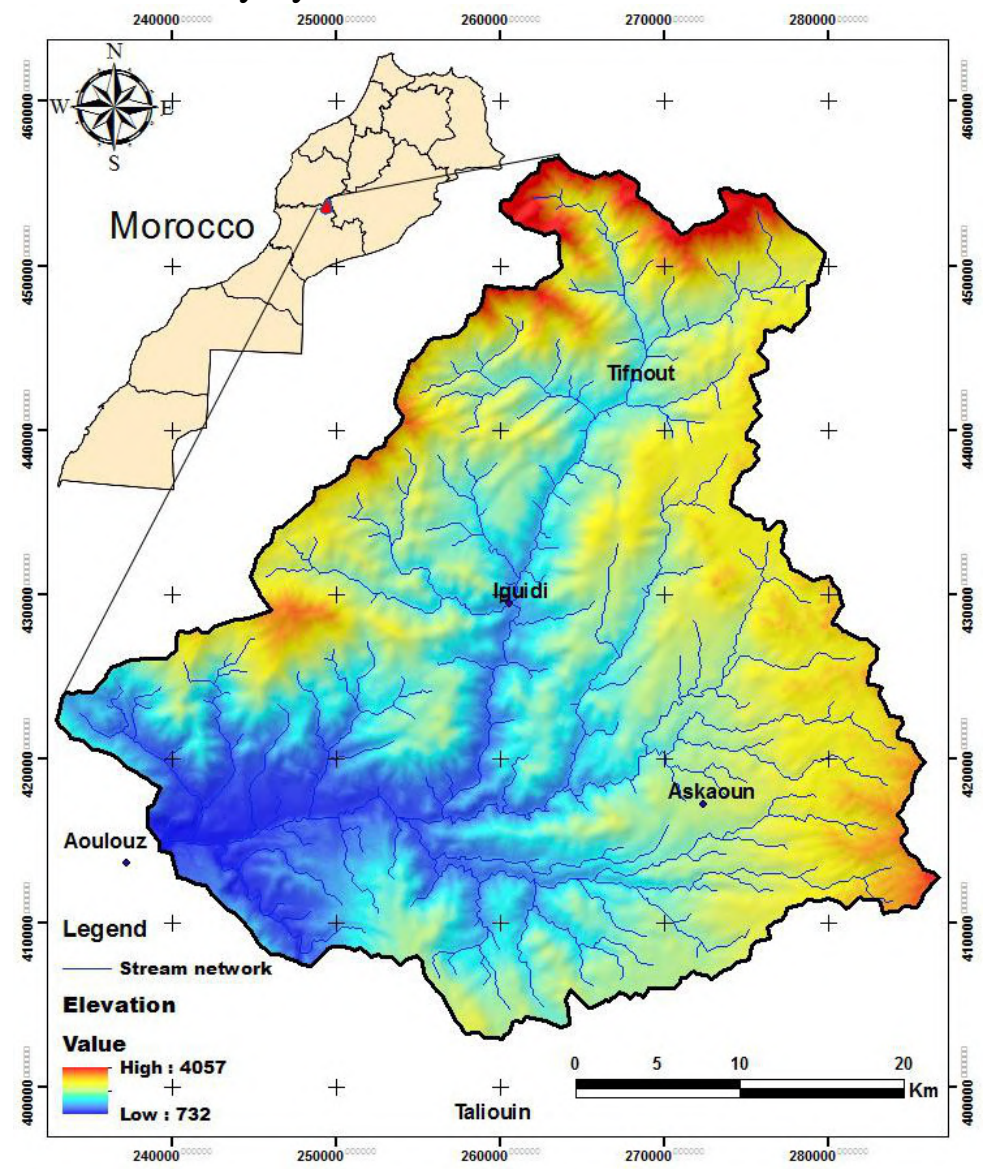

Figure 1: Geographical location of the study area

\section{Materiel and methods}

\section{Multi-criteria decisional mapping}

Several methods have been developed for the evaluation of erosion. We distinguish quantitative approaches (Wischmeier \& Smith, 1978), which calculate the rate of erosion in a precise manner, and which require a lot of 
data and a long-term follow-up. Also qualitative models, can be applied to characterize the erosion phenomenon in watersheds.

Among these qualitative methods, Hierarchical Multi-Criteria Analysis (AHP Analytical Hierarchy Process) developed by Saaty (1977), is the simplest of the multicriteria help methods. It is based on the synthesis and aggregation of weights assigned to the criteria of the different levels of the hierarchy (Table 1).

We chose the AHP method to combine the causal factors of water erosion in a hierarchical order and to delineate areas that may be at risk of erosion.

Table 1: Scale of comparisons of criteria (Saaty, 1977)

\begin{tabular}{|c|c|c|}
\hline Scale & $\begin{array}{c}\text { Verbal definition of the importance } \\
\text { of one factor over the other }\end{array}$ & \multirow{2}{*}{ More important } \\
\hline 9 & extremely & \\
\hline 7 & Very strong & \multirow{2}{*}{ Equally important } \\
\hline 5 & Strong & \multirow{2}{*}{ Less important } \\
\hline 3 & Moderately & \\
\hline 1 & Equally important & \\
\hline $1 / 3$ & Moderately & Strongly \\
\hline $1 / 5$ & Very Strongly & Extremely \\
\hline $1 / 7$ & &
\end{tabular}

\section{Pair wise comparison of the factors adopted}

To apply the Analytical Hierarchy Process (AHP), we will need to develop a pair wise comparison matrix of the 5 factors in a verbal order based on a good knowledge of the geomorphology of the study area and the importance of each factor in determining the susceptibility of the terrain to erosion according to the flowchart of Fig. 2.

The factors adopted in this study are:

$>$ S: the slope;

$>$ D: the density of drainage;

$>$ LU: land occupation;

$>$ K: soil erodibility and

$>$ R: the erosivity of the rains 


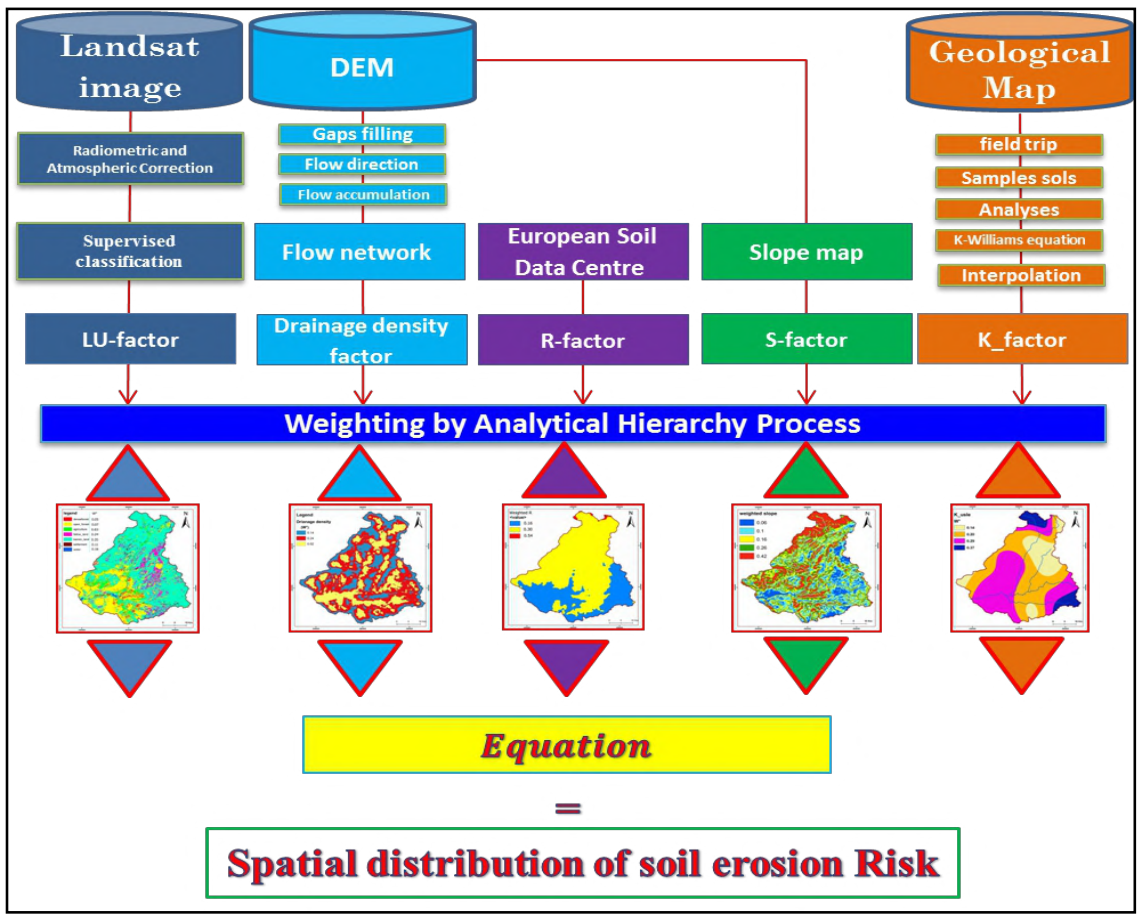

Figure 2: Methodological framework for the implementation of the AHP model for soil erosion risk.

The verbal judgments adopted were converted into ordinary values ranging from $1 / 5$ to 5 in a pair wise comparison matrix (Table 2).

Table 2: Comparison matrix of the 5 factors adopted

\begin{tabular}{|l|l|l|l|l|l|}
\hline & S & R & D & LU & K \\
\hline S & $\mathbf{1 . 0 0}$ & & & & \\
\hline R & 0.80 & $\mathbf{1 . 0 0}$ & & & \\
\hline D & 0.67 & 0.80 & $\mathbf{1 . 0 0}$ & & \\
\hline LU & 0.50 & 0.67 & 0.80 & $\mathbf{1 . 0 0}$ & \\
\hline K & 0.33 & 0.57 & 0.67 & 0.80 & $\mathbf{1 . 0 0}$ \\
\hline Sum & 3.30 & 4.29 & 5.22 & 6.55 & 8.50 \\
\hline
\end{tabular}

These verbal judgments are based on a good expert knowledge of the field and the importance of each factor in the phenomenon of erosion. To calculate the weights of each factor, we will need to convert each value in the table of the comparison matrix (Table 2) to a percentage of the sum per column. Then the weight of each factor is the average of each row of the standardized matrix (Table 3). 
Table 3: Standardized Matrix of Erosion Factors

\begin{tabular}{|l|l|l|l|l|l|l|l|}
\hline & $\mathrm{S}$ & $\mathrm{R}$ & $\mathrm{D}$ & $\mathrm{LU}$ & $\mathrm{K}$ & Weight $\%$ & $\mathrm{~W}^{\circ}$ \\
\hline $\mathrm{S}$ & 0.30 & 0.29 & 0.29 & 0.31 & 0.35 & $30.8 \%$ & 0.31 \\
\hline $\mathrm{R}$ & 0.24 & 0.23 & 0.24 & 0.23 & 0.21 & $23.0 \%$ & 0.23 \\
\hline $\mathrm{D}$ & 0.20 & 0.19 & 0.19 & 0.19 & 0.18 & $19.0 \%$ & 0.19 \\
\hline LU & 0.15 & 0.16 & 0.15 & 0.15 & 0.15 & $15.2 \%$ & 0.15 \\
\hline K & 0.10 & 0.13 & 0.13 & 0.12 & 0.12 & $12.0 \%$ & 0.12 \\
\hline & & & & & & & 1.00 \\
\hline
\end{tabular}

After calculating the weights of each factor the erosion will be evaluated by the following combination equation:

\section{SOIL EROSION RISK $=\sum_{0}^{n} W i * F i$}

Or :

$>$ Wi: weight of each factor;

$>$ Fi: factor.

To test the reliability of the judgments of the calculated matrix, it is necessary to calculate a coherence ratio (CR) (Saaty, 1977), the matrix is said to be coherent, only if the value of (RC) is less than 0.1 to say $(10 \%)$.

Consistency ratio $\quad \mathrm{CR}=\frac{\mathrm{CI}}{\mathrm{RI}}$

With :

CI is the coherence index $\quad \mathbf{C I}=(\boldsymbol{\lambda} \max -\mathbf{n}) /(\mathbf{n}-\mathbf{1})$;

$\mathbf{R I}$ is called (Random Index) the random index. Given by Saaty in (Table 4); for each n elements compared in the matrix;

$\lambda \max$ : maximum Eigen value.

Table 4: Random indices for matrices of comparisons (Saaty, 1984)

\begin{tabular}{|l|l|l|l|l|l|l|l|l|}
\hline $\boldsymbol{n}$ & 1 & 2 & 3 & 4 & 5 & 6 & 7 & 8 \\
\hline $\boldsymbol{R I}$ & 0 & 0 & 0.58 & 0.90 & 1.12 & 1.24 & 1.31 & 1.42 \\
\hline
\end{tabular}

Once the weighting is done, for the different factors adopted and the coherence ratio value is acceptable $\mathrm{RC}=0.02$, the superposition of the 5 input factors adopted will be carried out under the ArcGIS software 10.4.1 according to the following equation:

Risque $d^{\wedge \prime}$ érosion $=(0.31 * \mathbf{S})+(0.23 * \mathbf{R})+(0.19 * \mathbf{D})+(0.15 * \mathbf{L U})+(0.12 * \mathbf{K})$

\section{Elaboration and comparison by pair of the classes of each factor} The slope factor

The topographic factor is the major factor controlling the erosion phenomenon by the conditioning of the runoff velocity.

According to (Hudson, 1973 and Roose, 1994) particle transport increases with the length of the plot and exponentially with the degree and 
slope of the slope responsible for the occurrence of water erosion. (Savat \& De Ploey, 1982).

After developing the percentage slope map (Fig. 3), we performed a pair wise comparison of the slope classes according to the judgments of the matrix of (Table 5), based on the importance of each grade of slope in the erosion phenomenon to calculate the weight of each class (Table 6).

Table 5: Comparison matrix of slope classes in percentage.

\begin{tabular}{|c|c|c|c|c|c|}
\hline Slope classes & $\mathbf{> 2 0}$ & $\mathbf{1 5 - 2 0}$ & $\mathbf{1 0 t o 1 5}$ & $\mathbf{5}$ to $\mathbf{1 0}$ & $<\mathbf{5}$ \\
\hline$>\mathbf{2 0}$ & $\mathbf{1 . 0 0}$ & & & & \\
\hline $\mathbf{1 5 - 2 0}$ & 0.50 & $\mathbf{1 . 0 0}$ & & & \\
\hline $\mathbf{1 0 t o 1 5}$ & 0.33 & 0.50 & $\mathbf{1 . 0 0}$ & & \\
\hline $\mathbf{5}$ to 10 & 0.25 & 0.33 & 0.50 & $\mathbf{1 . 0 0}$ & \\
\hline$<\mathbf{5}$ & 0.20 & 0.25 & 0.33 & 0.50 & $\mathbf{1 . 0 0}$ \\
\hline Sum & 2.28 & 4.08 & 6.83 & 10.50 & 15.00 \\
\hline
\end{tabular}

Table 6: Standardized matrix of slope classes in percent

\begin{tabular}{|c|c|c|c|c|c|c|c|}
\hline Slope classes & $>20$ & $15-20$ & 10-15 & $5-10$ & $<5$ & Weight & $\mathbf{W}^{\circ}$ \\
\hline$>20$ & 0.44 & 0.49 & 0.44 & 0.38 & 0.33 & $41.6 \%$ & 0.42 \\
\hline $15-20$ & 0.22 & 0.24 & 0.29 & 0.29 & 0.27 & $26.2 \%$ & 0.26 \\
\hline 10-15 & 0.15 & 0.12 & 0.15 & 0.19 & 0.20 & $16.1 \%$ & 0.16 \\
\hline 5- 10 & 0.11 & 0.08 & 0.07 & 0.10 & 0.13 & $9.9 \%$ & 0.10 \\
\hline$<5$ & 0.09 & 0.06 & 0.05 & 0.05 & 0.07 & $6.2 \%$ & 0.06 \\
\hline
\end{tabular}
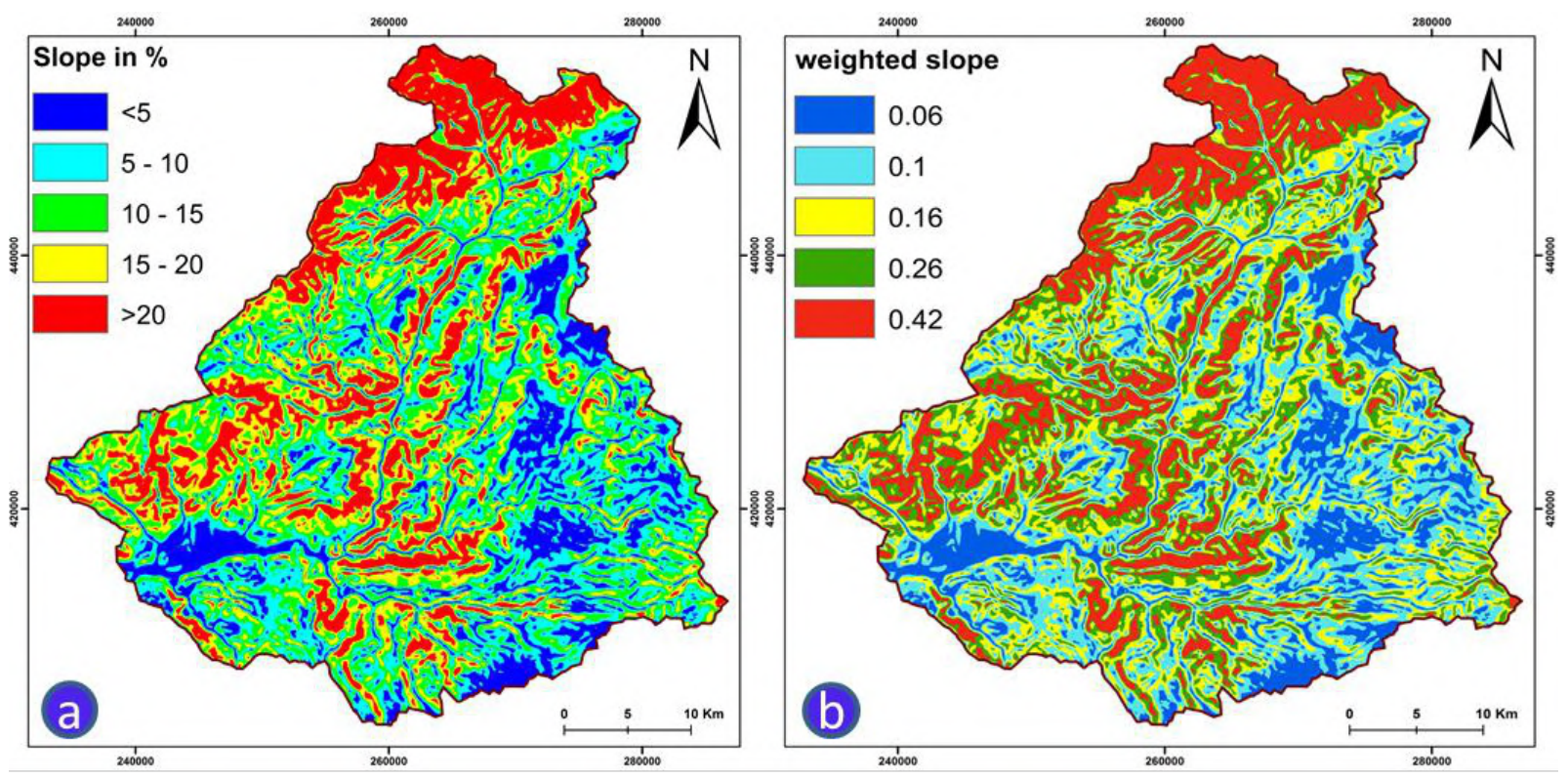

Figure 3 : (a) Slope map; (b) weighted slope map 


\section{The erosivity factor of the rains}

Rainfall energy on bare soils promotes sheet erosion (Ellison, 1944, 1946) (Le Bissonnais et al., 2002). The tearing off of soil particles is due to the action of raindrops, which are characterized by their falling speed controlled by the height of fall and the wind speed.

The $\mathrm{R}$ factor represents the susceptibility of detachment and displacement by soil particles by raindrops (Teng et al., 2018). The effect of the factor is increased by the intense effects of the accumulation of moderate rains. Wischmeier and Smith (1978).

In our case we used the global erosivity factor map $\mathrm{R}$ prepared by (Panagos et al., 2017) in the European Soil Data Center (ESDAC) for the world at a resolution of 30 arc-sec $(1 \times 1 \mathrm{~km}$ at the equator) based on the Gaussian Process Regression (GPR) (Fig. 4 (a)), whose rainfall data from 3625 meteorological stations in 63 countries were used. The equation adopted for the establishment of this map is as follows:

$$
\mathrm{R}=\frac{1}{n} \sum_{j=1}^{n} \sum_{k=1}^{m j}\left(E I_{30}\right) K
$$

Where EI30 is the rainfall-runoff erosivity of a single event $k, n$ the number of years observed and $\mathrm{mj}$. Erosive events in a given year $\mathrm{j}$.

The calculation of the erosivity of precipitation (EI30) for a single event was based on the following equation:

$$
E I_{30}=E . I
$$

Or $I_{30}$ is the maximum intensity of $30 \mathrm{~min}\left(I_{30}\right)$, E the kinetic rain energy of $1 \mathrm{~mm}$ from the rain in $\mathrm{MJ} \mathrm{ha}^{-1} \mathrm{~mm}^{-1}$, it is calculated from Brown et Foster (1987):

$$
E=0,29 .\left[1-0,72 e^{\left(-0.005 I_{r}\right)}\right]
$$

Where Ir is the rainfall intensity expressed in $\mathrm{mm} . \mathrm{h}^{\mathbf{- 1}}$.

The weighting of the R-factor classes was carried out according to the judgments of the matrix of (Table 7), where three classes were distinguished according to the importance of each class to favor a significant risk of water erosion, the weights adopted are represented in (Table.8) and (Fig.4 (b)).

Table 7: R-factor class comparison matrix

\begin{tabular}{|l|l|l|l|}
\hline Item Description & $\mathbf{8 3 0 - 1 0 8 5}$ & $\mathbf{5 7 0 - 8 3 0}$ & $\mathbf{3 1 5 - 5 7 0}$ \\
\hline $\mathbf{8 3 0 - 1 0 8 5}$ & 1.00 & & \\
\hline $\mathbf{5 7 0 - 8 3 0}$ & 0.50 & 1.00 & \\
\hline $\mathbf{3 1 5 - 5 7 0}$ & 0.33 & 0.50 & 1.00 \\
\hline sum & 1.83 & 3.50 & 6.00 \\
\hline
\end{tabular}


Table 8: Standardized matrix of R factor classes

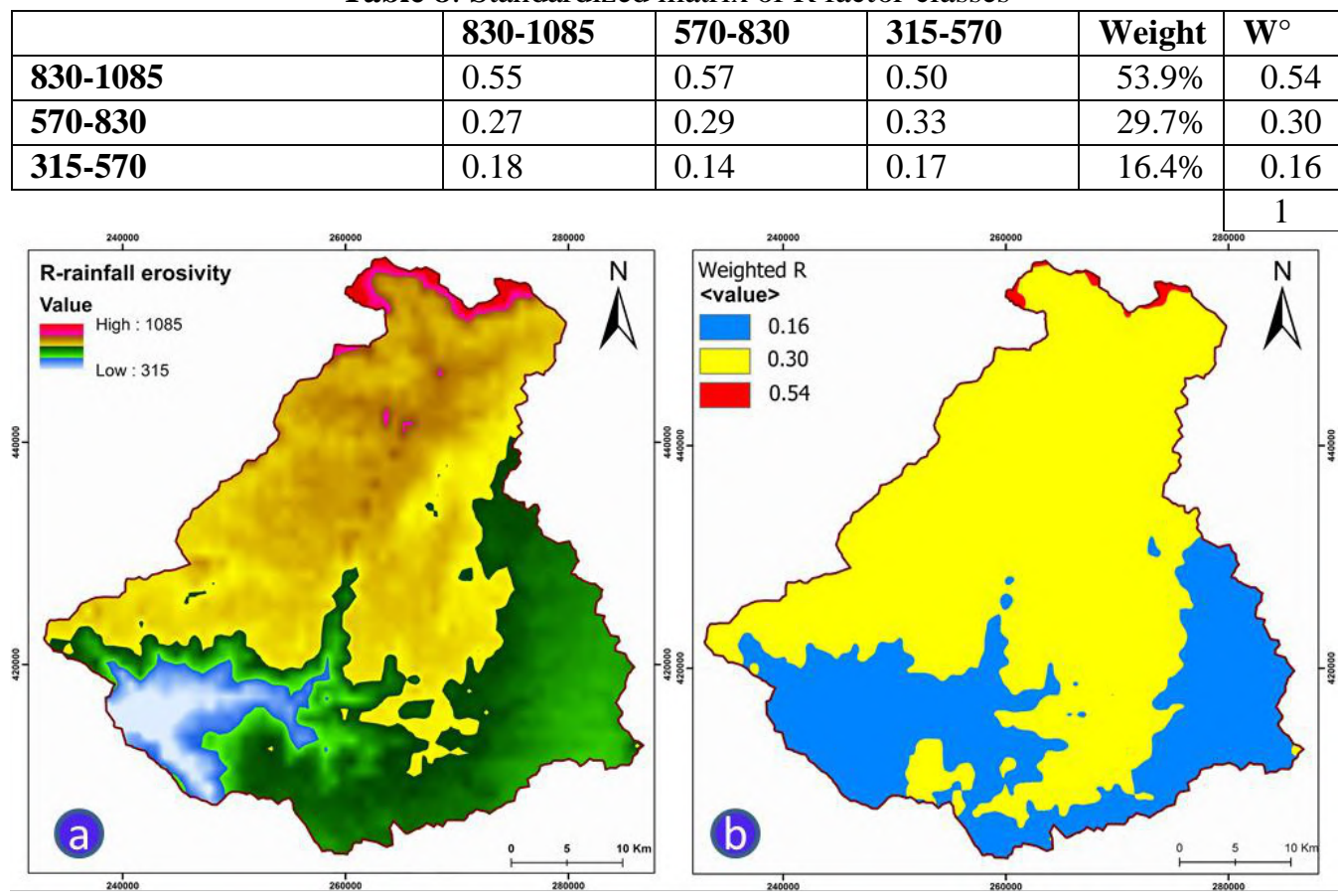

Figure 4: (a) R rainfall erosivity; (b) weighted rainfall erosivity

\section{Drainage density}

The study area is drained by several streams whose flow is almost permanent in Wadi Tifnout Valley and its tributaries draining the waters coming from the High Atlas to supply largely the two dams of Aoulouz and Mokhtar Soussi; these are also fed by the water of Askaoun wadi Valley and its tributaries located in the South-East of the study area.

To make the map of the hydrographic network in density, we used a DEM (Digital Elevation Model) with a resolution of 30m covering the study area according to the process of (Fig. 5):

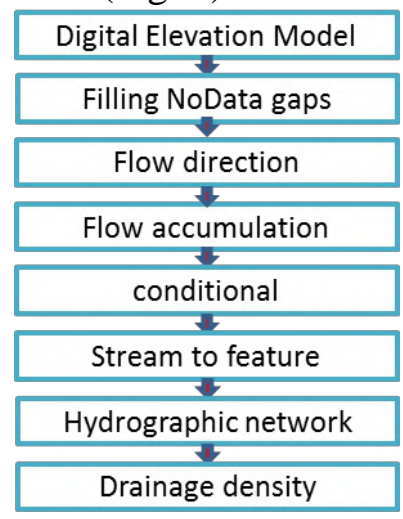

Figure 5: Stages of realization of the factor drainage density 
The hydrographic network of the Tifnout Askaoun watershed is well developed in the entire basin due to the imperviousness of magmatic rocks in the area, as well as restricted vegetation cover and very rugged terrain (Fig. 6 (a)).

Drainage density is the total length of the drainage system per unit area of the watershed. The calculation of this density was made dividing the total length of the hydrographic network of $1683.23 \mathrm{~km}$ by the total surface of the watershed which is of the order of $1570 \mathrm{~km}^{2}$. The value obtained $(1.07 \mathrm{~km} /$ $\mathrm{km}^{2}$ ) shows a high density of the network that will allow easy collection of runoff water and which could increase erosion.

Weighting of the drainage network factor was made based on the remoteness of the streams (Fig. 6 (b)), the weight of each class increases as it approaches the stream bed according to judgments of the matrixes (Tables 9.10).

Table 9: D-factor class comparison matrix

\begin{tabular}{|c|c|c|c|}
\hline Item Description & $\mathbf{1 1 5 - 2 0 0}$ & $\mathbf{8 0 - 1 1 5}$ & $\mathbf{1 0 - 8 0}$ \\
\hline $\mathbf{1 1 5 - 2 0 0}$ & $\mathbf{1 . 0 0}$ & & \\
\hline $\mathbf{8 0 - 1 1 5}$ & 0.33 & 1.00 & \\
\hline $\mathbf{1 0 - 8 0}$ & 0.25 & 0.50 & $\mathbf{1 . 0 0}$ \\
\hline sum & 1.58 & 4.50 & 7.00 \\
\hline
\end{tabular}

Table 10: Standardized matrix of factor D classes

\begin{tabular}{|c|c|c|c|c|c|}
\hline & $\mathbf{1 1 5 - 2 0 0}$ & $\mathbf{8 0 - 1 1 5}$ & $\mathbf{1 0 ~ 8 0}$ & Weight & $\mathbf{W}^{\circ}$ \\
\hline $\mathbf{1 1 5 - 2 0 0}$ & 0.63 & 0.67 & 0.57 & $62.3 \%$ & 0.62 \\
\hline $\mathbf{8 0 - 1 1 5}$ & 0.21 & 0.22 & 0.29 & $23.9 \%$ & 0.24 \\
\hline $\mathbf{1 0 ~ 8 0}$ & 0.16 & 0.11 & 0.14 & $13.7 \%$ & 0.14 \\
\cline { 5 - 6 }
\end{tabular}
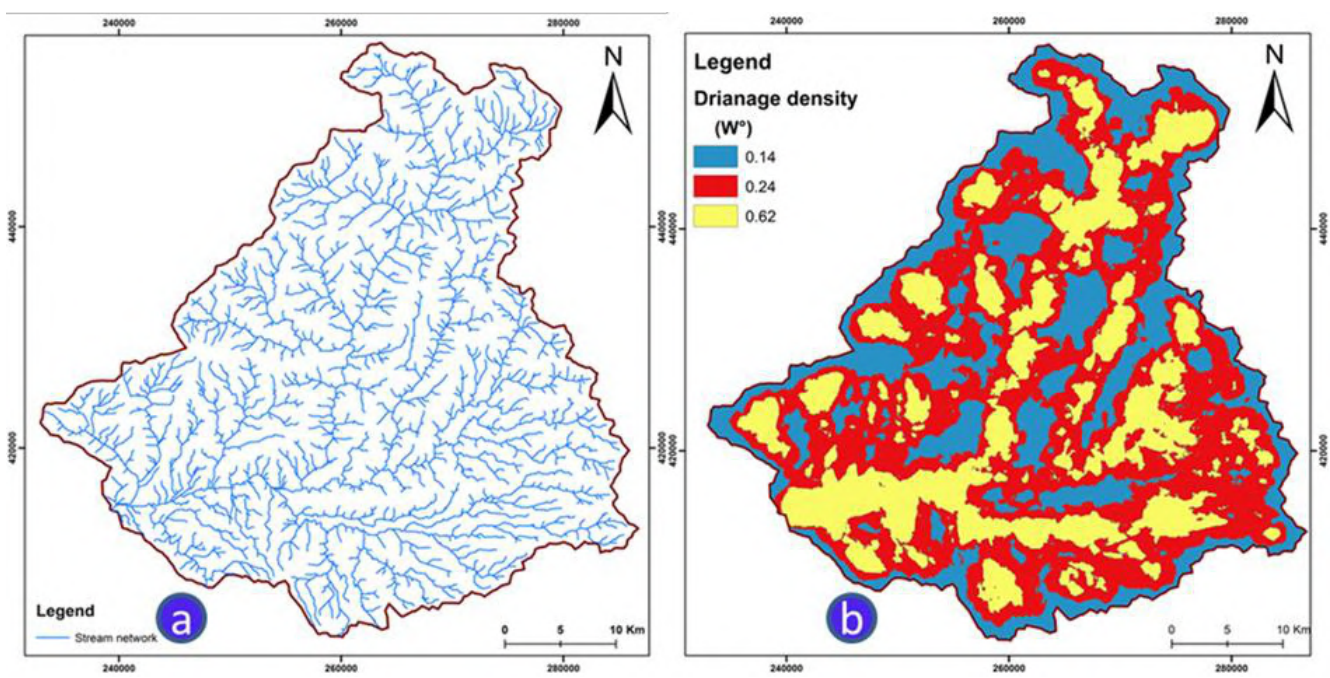

Figure 6: (a) Hydrographic network; (b) density of the hydrographic network 


\section{Land use}

To determine the weights of the land use classes of the study area; a landsat_8_oli image has been classified using the maximum likehood likelihood option in the land use classes map and weighted according to the matrices of (Table $11 \& 12$ ) based on the importance of each class.

Table 11: LU factor class comparison matrix

\begin{tabular}{|l|l|l|l|l|l|l|l|}
\hline $\begin{array}{l}\text { Item } \\
\text { Description }\end{array}$ & $\begin{array}{l}\text { Barren } \\
\text { land }\end{array}$ & $\begin{array}{l}\text { Fallow } \\
\text { land }\end{array}$ & Water & Settlement & $\begin{array}{l}\text { Open } \\
\text { forest }\end{array}$ & $\begin{array}{l}\text { Dense } \\
\text { forest }\end{array}$ & $\begin{array}{l}\text { Agricultural } \\
\text { land }\end{array}$ \\
\hline Barren land & $\mathbf{1 . 0 0}$ & & & & & & \\
\hline Fallow land & 0.50 & $\mathbf{1 . 0 0}$ & & & & & \\
\hline Water & 0.33 & 0.50 & $\mathbf{1 . 0 0}$ & & & & \\
\hline Settlement & 0.25 & 0.33 & 0.50 & $\mathbf{1 . 0 0}$ & & & \\
\hline Open forest & 0.20 & 0.25 & 0.33 & 0.50 & $\mathbf{1 . 0 0}$ & & \\
\hline Dense forest & 0.17 & 0.20 & 0.25 & 0.33 & 0.50 & $\mathbf{1 . 0 0}$ & \\
\hline $\begin{array}{l}\text { Agricultural } \\
\text { land }\end{array}$ & 0.14 & 0.17 & 0.20 & 0.25 & 0.33 & 0.50 & $\mathbf{1 . 0 0}$ \\
\hline Sum & 2.59 & 4.45 & 7.28 & 11.08 & 15.83 & 21.50 & 28.00 \\
\hline
\end{tabular}

Tableau 12: Standardized matrix of the classes of the land use factor (LU)

\begin{tabular}{|l|l|l|l|l|l|l|l|l|l|}
\hline & $\begin{array}{l}\text { Barren } \\
\text { land }\end{array}$ & $\begin{array}{l}\text { Fallow } \\
\text { land }\end{array}$ & Water & Settlement & $\begin{array}{l}\text { Open } \\
\text { forest }\end{array}$ & $\begin{array}{l}\text { Dense } \\
\text { forest }\end{array}$ & $\begin{array}{l}\text { Agricultural } \\
\text { land }\end{array}$ & Weight & $\mathbf{W}^{\circ}$ \\
\hline Barren land & 0.39 & 0.45 & 0.41 & 0.36 & 0.32 & 0.28 & 0.25 & $35.0 \%$ & 0.35 \\
\hline Fallow land & 0.19 & 0.22 & 0.27 & 0.27 & 0.25 & 0.23 & 0.21 & $23.7 \%$ & 0.24 \\
\hline Water & 0.13 & 0.11 & 0.14 & 0.18 & 0.19 & 0.19 & 0.18 & $15.9 \%$ & 0.16 \\
\hline Settlement & 0.10 & 0.07 & 0.07 & 0.09 & 0.13 & 0.14 & 0.14 & $10.6 \%$ & 0.11 \\
\hline Open forest & 0.08 & 0.06 & 0.05 & 0.05 & 0.06 & 0.09 & 0.11 & $7.0 \%$ & 0.07 \\
\hline Dense forest & 0.06 & 0.04 & 0.03 & 0.03 & 0.03 & 0.05 & 0.07 & $4.6 \%$ & 0.05 \\
\hline $\begin{array}{l}\text { Agricultural } \\
\text { land }\end{array}$ & 0.06 & 0.04 & 0.03 & 0.02 & 0.02 & 0.02 & 0.04 & $3.2 \%$ & 0.03 \\
\hline
\end{tabular}




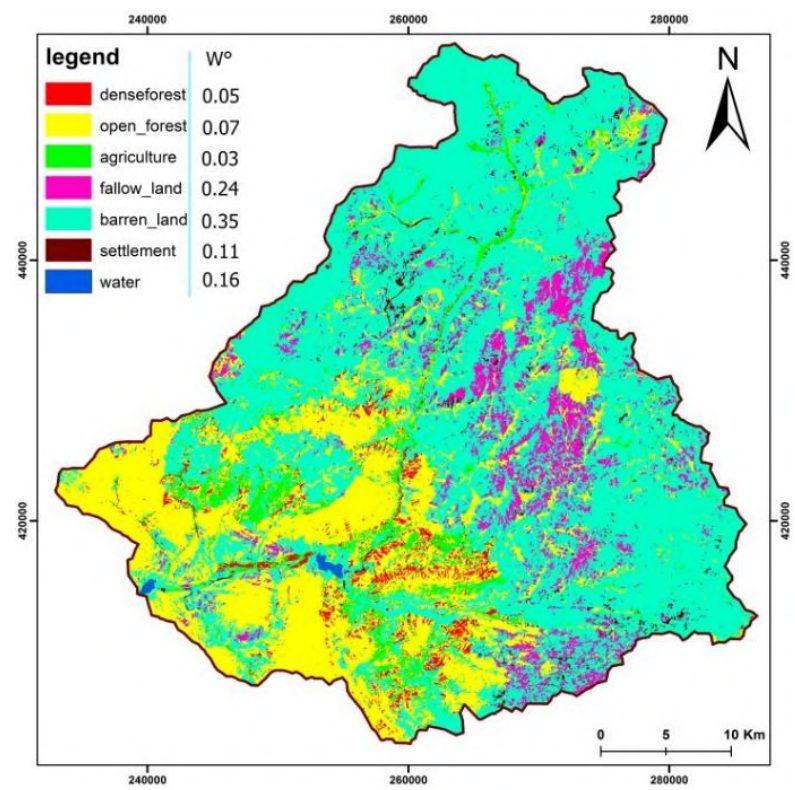

Figure 7: Land use weighted classes of the study area

\section{The $\mathrm{K}$ factor}

The $\mathrm{K}$ factor represents the influence of different soil properties on the slope's susceptibility to erosion (Renard et al., 1997). It is defined as the "average annual loss rate of rainfall" for a "standard condition of bare soil, recently tilled up-and-down slope with no conservation practice" (Morgan, 2005). The K factor essentially represents the soil loss that would occur on the USLE unit plot, which is a plot that is $22.1 \mathrm{~m}$ long, is $1.83 \mathrm{~m}$ wide, and has a slope of 9\% (Lopez-Vicente et al. 2008).

Erodibility is closely related to soil infiltration capacity, structural stability, and percentage of organic matter present (Saaty , 1977, Roose, 1994).

Soil size plays an important role in the erodibility factor: the more the silt fraction increases over clay and sand, the more soil becomes erodible. Thus, in a structurally stable soil with high organic matter content, the runoff rates decreases and, consequently, the rate of erosion also (Kacem et al., 2017).

To develop the K-factor map, a total of 24 soil samples were taken from the study area and analyzed for their characteristics.

Particle size analysis was carried out in the Laboratory of Applied Geology and Geo-Environment of the Faculty of Science at Ibn Zohr University Agadir Morocco. 
$\mathrm{K}$-factor values for the study area were calculated by the equation of (Williams and Renard 1983, cited in Chen et al. (2011)) (table 15):

$$
\begin{gathered}
\mathbf{K}=0.2+0.3 \exp \left(0.0256 * S a *\left(1-\frac{S i}{100}\right)\right) \\
*\left(\frac{S i}{C l+S i}\right)^{0.3} *\left(1-\frac{0.25 * C}{C+\exp (3.72-2.95 C)}\right) \\
*\left(1-\frac{0.7 * S N}{S N+\exp (-5.51+22.9 S N}\right)
\end{gathered}
$$

With :

$\checkmark$ Sa : Sand \% ; Si :Silt\%; Cl :Clay\%; C :Organic carbon\% and $\mathrm{SN}=\mathbf{1}-\left(\frac{S a}{\mathbf{1 0 0}}\right)$.

The factor $\mathrm{K}$ map is obtained by interpolation based on the calculated values of $\mathrm{K}$ by the previous formula for the 24 sampling points of the study area (Fig. 8 (a)).

Depending on the K values obtained, four classes of soil sensitivity to erosion were selected; the weak sensitivity [0.23-0.32], the average sensitivity $[0.32-0.38]$, the high sensitivity [0.38-0.45] and the very high sensitivity [0.45$0.58]$.

The weighting of the K factor in Fig. 8 (b) was performed on the basis of the importance of the $\mathrm{K}$-factor values according to the comparison matrix judgments of (Tables 13.14).

Table 13: K-factor class comparison matrix

\begin{tabular}{|c|c|c|c|c|}
\hline $\begin{array}{c}\text { Item } \\
\text { Description }\end{array}$ & $\mathbf{0 . 4 5}-\mathbf{0 . 5 8}$ & $\mathbf{0 . 3 8}-\mathbf{0 . 4 5}$ & $\mathbf{0 . 3 2}-\mathbf{0 . 3 8}$ & $\mathbf{0 . 2 3}-\mathbf{0 . 3 2}$ \\
\hline $\mathbf{0 . 4 5}-\mathbf{0 . 5 8}$ & $\mathbf{1 . 0 0}$ & & & \\
\hline $\mathbf{0 . 3 8}-\mathbf{0 . 4 5}$ & 0.80 & $\mathbf{1 . 0 0}$ & & \\
\hline $\mathbf{0 . 3 2}-\mathbf{0 . 3 8}$ & 0.50 & 0.67 & $\mathbf{1 . 0 0}$ & \\
\hline $\mathbf{0 . 2 3}-\mathbf{0 . 3 2}$ & 0.40 & 0.50 & 0.67 & $\mathbf{1 . 0 0}$ \\
\hline Sum & 2.70 & 3.42 & 5.17 & 7.00 \\
\hline
\end{tabular}

Table 14: Standardized matrix of K-factor classes

\begin{tabular}{|l|c|c|c|c|l|l|}
\hline & $\mathbf{0 . 4 5 - 0 . 5 8}$ & $\mathbf{0 . 3 8 - 0 . 4 5}$ & $\mathbf{0 . 3 2 - 0 . 3 8}$ & $\mathbf{0 . 2 3 - 0 . 3 2}$ & Weight \% & Weight \\
\hline $\mathbf{0 . 4 5 - 0 . 5 8}$ & 0.37 & 0.37 & 0.39 & 0.36 & $37.0 \%$ & 0.37 \\
\hline $\mathbf{0 . 3 8 - 0 . 4 5}$ & 0.30 & 0.29 & 0.29 & 0.29 & $29.1 \%$ & 0.29 \\
\hline $\mathbf{0 . 3 2 - 0 . 3 8}$ & 0.19 & 0.20 & 0.19 & 0.21 & $19.7 \%$ & 0.20 \\
\hline $\mathbf{0 . 2 3 - 0 . 3 2}$ & 0.15 & 0.15 & 0.13 & 0.14 & $14.2 \%$ & 0.14 \\
\hline \multicolumn{7}{|l|}{} \\
\hline
\end{tabular}


Table 15: The physical properties of soil samples for the calculation of $\mathrm{K}$-factor

\begin{tabular}{|c|c|c|c|c|c|c|c|c|c|}
\hline $\begin{array}{c}\text { Soil } \\
\text { samples }\end{array}$ & $\begin{array}{l}\text { Sand(\%) } \\
\text { Topsoil }\end{array}$ & Silt (\%) Topsoil & $\begin{array}{c}\text { mc (clay) } \\
\text { Topsoil)\% }\end{array}$ & $\underset{\%}{\text { OC org carbon }}$ & Fcsand & F cl-si & F orgc & F hisand & $\begin{array}{c}\text { K } \\
\text { usle }\end{array}$ \\
\hline 1 & $30.11 \%$ & $48.56 \%$ & $18.57 \%$ & $2.06 \%$ & 0.4778452 & 0.9074184 & 0.9998677 & 1 & 0.434 \\
\hline 2 & $46.40 \%$ & $33.57 \%$ & $18.57 \%$ & $1.69 \%$ & 0.4665061 & 0.8762433 & 0.9998927 & 1 & 0.409 \\
\hline 3 & $77.86 \%$ & $7.13 \%$ & $12.86 \%$ & $0.25 \%$ & 0.4458226 & 0.7339101 & 0.9999848 & 1 & 0.327 \\
\hline 4 & $35.09 \%$ & $41.25 \%$ & $22.86 \%$ & $1.94 \%$ & 0.4743305 & 0.8761136 & 0.9998755 & 1 & 0.416 \\
\hline 5 & $56.54 \%$ & $24.89 \%$ & $17.14 \%$ & $1.12 \%$ & 0.4596652 & 0.8545326 & 0.9999302 & 1 & 0.393 \\
\hline 6 & $66.37 \%$ & $16.33 \%$ & $15.71 \%$ & $1.35 \%$ & 0.4531922 & 0.8168724 & 0.9999151 & 1 & 0.370 \\
\hline 7 & $55.54 \%$ & $20.15 \%$ & $22.86 \%$ & $1.12 \%$ & 0.4603116 & 0.7965476 & 0.9999297 & 1 & 0.367 \\
\hline 8 & $44.66 \%$ & $42.31 \%$ & $12.86 \%$ & $1.94 \%$ & 0.4677206 & 0.9234897 & 0.9998755 & 1 & 0.432 \\
\hline 9 & $56.51 \%$ & $35.23 \%$ & $7.14 \%$ & $1.99 \%$ & 0.459723 & 0.9461243 & 0.9998724 & 1 & 0.435 \\
\hline 10 & $73.40 \%$ & $12.12 \%$ & $12.86 \%$ & $0.80 \%$ & 0.4486649 & 0.8049864 & 0.9999503 & 1 & 0.361 \\
\hline 11 & $71.86 \%$ & $17.12 \%$ & $10.00 \%$ & $2.22 \%$ & 0.4496708 & 0.8710944 & 0.9998565 & 1 & 0.392 \\
\hline 12 & $61.17 \%$ & $24.25 \%$ & $12.86 \%$ & $1.93 \%$ & 0.4566115 & 0.8801952 & 0.9998764 & 1 & 0.402 \\
\hline 13 & $51.74 \%$ & $21.04 \%$ & $25.71 \%$ & $1.07 \%$ & 0.4628542 & 0.7869587 & 0.9999328 & 1 & 0.364 \\
\hline 14 & $67.34 \%$ & $16.33 \%$ & $15.71 \%$ & $1.97 \%$ & 0.4525644 & 0.8168953 & 0.9998738 & 1 & 0.370 \\
\hline 15 & $69.71 \%$ & $17.21 \%$ & $14.29 \%$ & $1.95 \%$ & 0.4510422 & 0.8342065 & 0.9998747 & 1 & 0.376 \\
\hline 16 & $73.38 \%$ & $9.36 \%$ & $15.71 \%$ & $2.14 \%$ & 0.4486647 & 0.7440425 & 0.999862 & 1 & 0.334 \\
\hline 17 & $77.84 \%$ & $4.30 \%$ & $17.14 \%$ & $1.94 \%$ & 0.4458196 & 0.6174923 & 0.9998755 & 1 & 0.275 \\
\hline 18 & $57.30 \%$ & $34.56 \%$ & $7.14 \%$ & $1.60 \%$ & 0.4592004 & 0.9451915 & 0.9998985 & 1 & 0.434 \\
\hline 19 & $49.68 \%$ & $35.21 \%$ & $17.14 \%$ & $2.29 \%$ & 0.4642907 & 0.8878087 & 0.9998519 & 1 & 0.412 \\
\hline 20 & $58.90 \%$ & $24.12 \%$ & $15.71 \%$ & $2.47 \%$ & 0.4581039 & 0.8602636 & 0.999839 & 1 & 0.394 \\
\hline 21 & $57.82 \%$ & $32.11 \%$ & $10.00 \%$ & $2.47 \%$ & 0.4588474 & 0.9218888 & 0.9998393 & 1 & 0.423 \\
\hline 22 & $71.28 \%$ & $10.28 \%$ & $21.14 \%$ & $1.04 \%$ & 0.4500081 & 0.7151543 & 0.9999353 & 1 & 0.322 \\
\hline 23 & $61.60 \%$ & $15.22 \%$ & $22.86 \%$ & $1.91 \%$ & 0.4562943 & 0.7595082 & 0.9998776 & 1 & 0.347 \\
\hline 24 & $60.80 \%$ & $19.21 \%$ & $20.00 \%$ & $1.51 \%$ & 0.4568349 & 0.8073142 & 0.9999044 & 1 & 0.369 \\
\hline
\end{tabular}




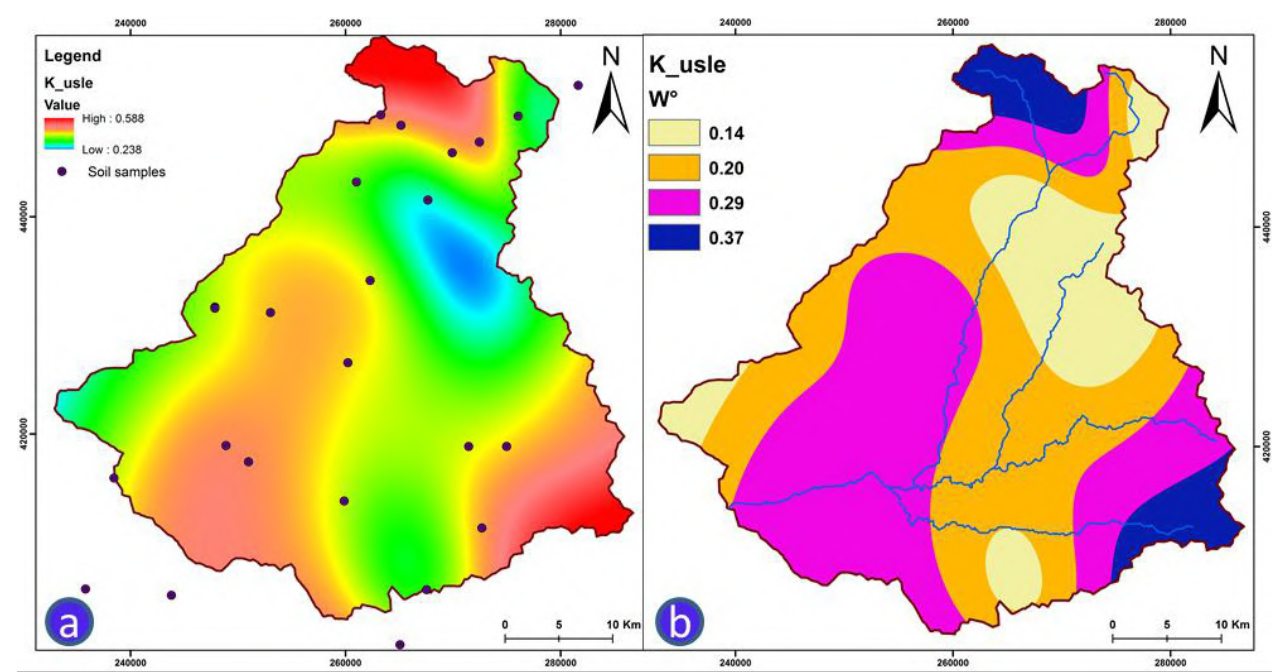

Figure 8: (a) Interpolation of values obtained from K, (b) weighted map of factor $\mathrm{K}$

The obtained results for the $\mathrm{K}$ factor after interpolation at the scale of the Tifnout-Askaoun catchments vary from 0.23 t.ha.h / ha.MJ.mm for the most resistant soils to 0.58 t.ha.h / ha.MJ .mm for the most erodible soils.

The soils in the study area are considered to be erosion-sensitive soils as the average of their erodibility index $\mathrm{K}$ and 0.40 t.ha.h / ha.MJ.mm. An overview on the $\mathrm{K}$ factor map shows that the highest $\mathrm{K}$ values are south-east in the Askoun area, north-east near Ifni Lake and south around the Ouzioua and Aoulouz dams.

\section{Results and discussion}

The model applied in this study allows determining the zones sensitive to soil erosion in the Tifnout Askaoun basin.

Based on the sensitivity classes of the factors that control the erosion phenomenon we have established the distribution map of the risk of soil erosion in the Tifnout Askaoun watershed (Fig. 9) by the combination of the various factors mentioned above, using Arcgis 10.4.1 software according to the following equation:

$$
\text { Risque d'érosion }=(0.31 * \mathbf{S})+(0.23 * \mathbf{R})+(0.19 * \mathbf{D})+(0.15 * \mathbf{L U})+(0.12 * \mathbf{K})
$$

We classified the soil loss risk map into 4 classes according to the intensity of erosion. The first class [0.10 -0.19] for a low risk of soil loss, the class [0.19-0.24] for an average risk of soil loss, the class [0.24-0.29] for a high risk of soil loss, and finally the class [0.29-0.41] for a very high risk of soil loss.

The figure shows the spatial distribution of each class of soil loss risk in percent developed by the AHP method; we note that more than $48 \%$ of the study area presents a high to very high risk (Fig. 10). 
The result obtained shows that the risk of erosion increases going from the Anti Atlas in the East and the plain of Souss in the south towards the high altitudes of the High Atlas in the North. The risk is very strong in the north where the slope is very strong, and the vegetation cover is almost rare. Also factor $\mathrm{K}$ plays a very important role as the high values calculated for this factor exists in the north of the study area in the town of Toubkal near Lake Ifni.

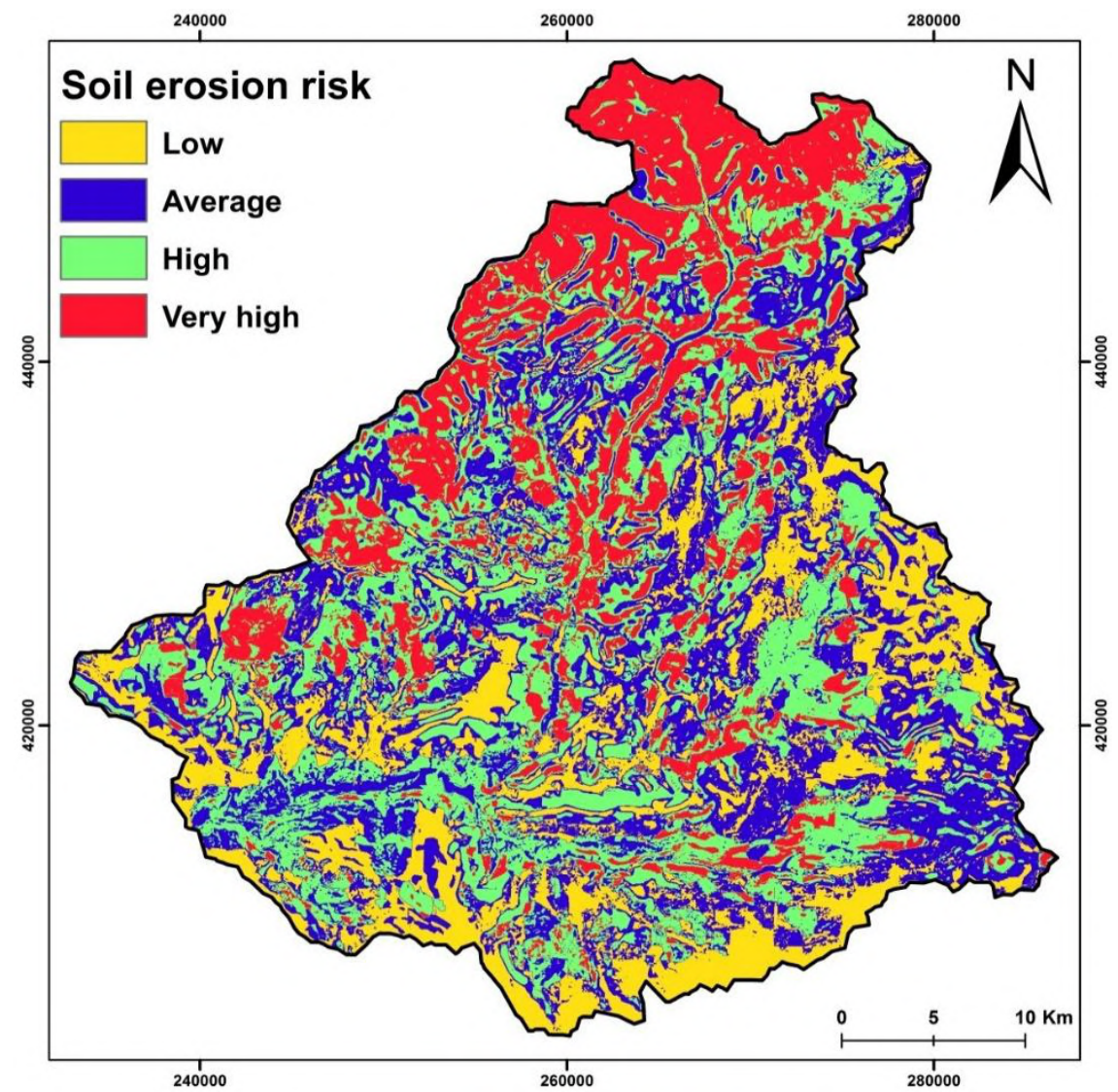

Figure 9: Map of soil erosion risk in the Tifnout Askaoun watershed

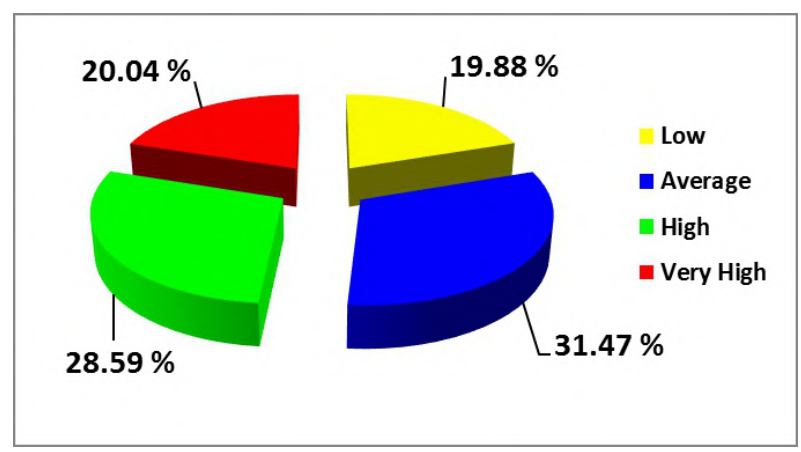

Figure 10: Class distribution of soil loss risk 
In order to characterize the degree of risk of soil loss in the Tifnout Askaoun watershed, we have subdivided our study area into 23 subwatersheds (Fig. 11) to identify the sub-basins most threatened by erosion and which deserve priority in future interventions against erosion. We note that sub-watershed 1 (Toubkal) and sub-watershed 2 (Ikiss) are the most affected by the erosion phenomenon as the very high risk class occupies the majority of these two watersheds.

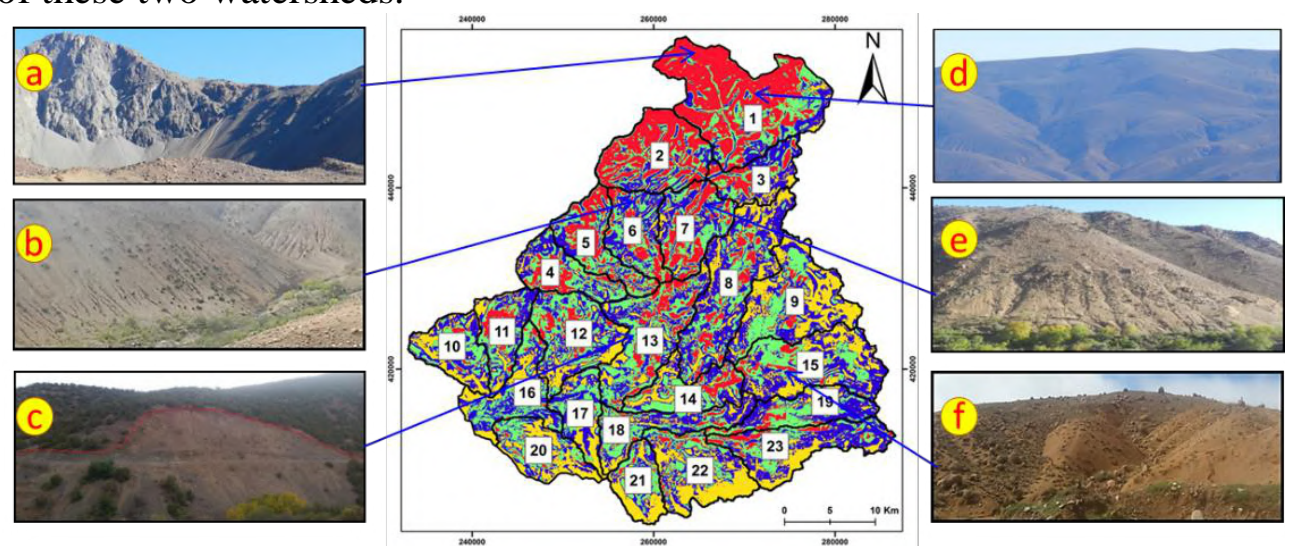

Figure 11: Watersheds of the study area

$>$ a: Toubkal erosion cones;

b: ravines Azgurouz;

$>$ c: Landslide Ouzioua;

$>\mathrm{d}$ and $\mathrm{e}:$ Toubkal and Tifnout ravines;

$>$ f: Askaoun badland..

\section{Conclusion}

This study proposes a qualitative approach based on three concepts: the hierarchical decomposition of the problem dealt with in sub-problems, the classification of the elements according to their relative importance and the logical coherence of the opinions used. The weight identified for each criterion comes from a mathematical formulation that uses a binary comparison scale. The result obtained is evaluated with respect to a random coherence index which the coherence ratio $\mathrm{RC}$ whose values obtained are less than 0.1 , make it possible to validate the comparison matrices made.

The mapping of areas at risk of erosion at the Tifnout Askaoun watershed was carried out using the AHP (Analytical Hierarchy Process) integrated in a Geographic Information System (GIS). The method used provides a strong database to decision makers to simulate scenarios of erosion in the region and to plan erosion control interventions.

The results obtained show that the soils of the Tifnout Askaoun watershed are affected by several factors favoring erosion, namely, the steep 
slope, the scarcity of vegetation cover and the erodibility of soils. It should also be noted that half of the watershed is subject to a high or very high risk of soil loss. This rather serious situation is favored by the various factors of erosion, which, by assembling accelerate erosion, soil in the study area.

\section{References:}

1. Al Raisi,S.A.H., Sulaiman,H., Abdallah,O., Suliman,F.E. (2014). Landfill suitablity analysis using AHP method and state of heavy metals pollution in selected landfills in Oman. European Scientific Journal, vol.10, No.17.

http://eujournal.org/index.php/esj/article/view/3565/3405;

2. Bou kheir, R., Cerdan, O \& Abdelah, C. (2006). Regional soil erosion risk mapping in Lebanon. Geomorphology, 82, 347-359. https://doi.org/10.1016/j.geomorph.2006.05.012

3. Brown, L.C., \& Foster, G.R. (1987). Storm erosivity using idealized intensity distributions. Am. Soc. Agricult. Biol. Eng., 30, 0379-0386.

4. Chen, L., Qian, X.\& Shi, Y. (2011). Critical Area Identification of Potentia 1Soil Loss in a Typical Watershed of the Three Gorges Reservoir Region. Water. Resour. Manage., 25, 3445-3463. https://doi.org/10.1007/s11269-011-9864-4

5. Ellison, W.D. (1944). Two devices for measuring soil erosion. Agricultural Engineering, 25, 53-55.

6. Ellison, W.D. (1946). Soil detachment and transportation. Soil Conservation, 11, 179, 190.

7. Elmouden, A., 2017. évaluation et cartographie de l'érosion hydrique des bassins versant via la quantification de l'envasement des barrages; cas du basin hydrologique Souss-Massa Maroc. Thèse de doctorat Ibn Zohr university, Morocco.

8. Hudson, N.W. (1973). .Soil conservation, Batsford ,London ; 320 p.

9. Kacem, L., Agoussine, M., Igmoullan, B., Amar, H., Mokhtari, S. \& Ait Brahim, Y. (2017) Application de la méthode d'analyse multicritère hiérarchique pour la quantification de perte en sol dans un sous-bassin montagnard -haute vallée de Tifnoute (Haut Atlas marocain). Geo-Eco-Trop., 41, 493-502. http://www.geoecotrop.be/uploads/publications/pub_413_13.pdf

10. Le Bissonnais, Y., Thorette, J., Bardet, C., \& Daroussin, J. (2002). L'érosion hydrique des sols en France, INRA, IFEN, 106 p.

11. Lopez-Vicente, M., Navas, A. \& Mach, J. (2008). Identifying erosive periods by using RUSLE factors in mountain fields of the Central Spanish Pyrenees. Hydrol. Earth Syst. Sci 12, 523-535. https://doi.org/10.5194/hess-12-523-2008 
12. Morgan, R. (2005). Soil erosion and conservation. European journal of soil science,56, 681-687. https://doi.org/10.1111/j.13652389.2005.0756f.x

13. Panagos, P., Borrelli, P., Meusburger, K., Yu, B., Klik, A., Lim, K.J., Yang, J.E., Ni, J., Miao, C., Chattopadhyay, N., Sadeghi, S.H., Hazbavi, Z., Zabihi, M., Larionov, G.A., Krasnov, S.F., Gorobets, A.V., Levi, Y., Erpul, G., Birkel, C., Hoyos, N., Naipal, V., Oliveira, P.T.S., Bonilla, C.A., Meddi, M., Nel, W., Al Dashti, H., Boni, M., Diodato, N., Van Oost, K., Nearing, M., \& Ballabio, C. (2017). Global rainfall erosivity assessment based on high-temporal resolution rainfall records. Sci. Rep. 7. http://dx.doi.org/10.1038/s41598-017-04282-8.

14. Renard, K. G., Foster, G. R., Weesies, G., Mc Cool, D. K., \& Yoder, D. C. (1997). Predicting soil erosion by water: A guide to conservation planning with the Revised Universal Soil Loss Equation RUSLE. USDA Agricultural Handbook, No. 703.

15. Roose, E. (1994). Introduction à la GCES. Bulletin pédologique FAO, Rome, $70-420$.

16. Saaty, T.L. (1977). A scaling method for priorities in hierarchical structures. Journal of Mathematical Psychology, 15,234-281.

17. Savat, J. \& De Ploey, J. (1982). Sheetwash and rill development by surface flow. Badland geomorphology and piping, Bryan R. and Yair a. (eds), Geobooks Norwich (Angleterre), 113- 126.

18. Teng, H., Liang, Z., Chen, S., Liua, Y., Rossel, R. A. V., Chappell, A., Yuf, W. \& Shi, Z. (2018). Current and future assessments of soil erosion by water on the Tibetan Plateau based on RUSLE and CMIP5 climate models. Science of the Total Environment, 635, 673 686.https://doi.org/10.1016/j.scitotenv.2018.04.146

19. Williams, R. J., \& Renard, K. G. (1983). a new method for assessing erosions effect on soil productivity. Soil Water Conserv.,38, 381-383. http://www.jswconline.org/content/38/5/381.short

20. Wischmeier W. \& Smith D. (1978). Predicting rainfall erosion losses A guide to conservation planning.U.S. Department of Agriculture Handbook, 537. 